\title{
Uranium mining: post-closure land uses - a personal global review
}

\author{
PW Waggitt Consultant, Australia
}

\begin{abstract}
The mining industry has a long and chequered reputation when it comes to remediation, closure and postmining land use. There are, sadly, too many poor examples around the world of abandoned mines and remediation projects that have failed to live up to expectations. Modern society has great expectations and high standards that they expect to see enforced when new mining projects are being assessed for development. It is therefore important for the global mining industry to be able to demonstrate that there are examples of useful post-closure uses for former mining sites. In the case of uranium mining, which carries the additional 'stigma' of radioactivity it is even more important to show that mining, even uranium mining, need not be a one-time user of land.

This paper describes a selection of former uranium mining sites from around the world where remediation has been completed, or is ongoing, and post-mining land use has been established or is nearing completion. The examples are drawn from Europe, the United States of America and Australia.
\end{abstract}

Keywords: remediation, post-closure land use, uranium mining, balanced mining

\section{Introduction}

Mining has been with us for centuries and it seems always to have been associated with concerns that whilst the operations provide society with great benefits including raw materials, fertiliser and employment, there is also a long history of legacies from former mining operations. The first example of this is evidenced in De Re Metallica; that great volume first published in 1556 by Agricola (Agricola 1556). There he expressed concerns about loss of trees and farmland, damage to crops and long lasting impacts on soil, water and even the air. Sadly over the next 300+ years not a great deal changed with our planet strewn with examples of abandoned mine sites, open pits, waste rock dumps, tailings dams and ponds, open shafts and adits, eroding landscapes, unhealthy waterways and so on.

Whilst all types of mines, especially metalliferous ones, have contributed to this legacy list there are some cases where there may be extra concerns for society to cope with. The case of uranium mines is one of these. Uranium is a heavy metal and should be managed and respected as other heavy metals in terms of environmental and health risks; but the additional presence of its radioactive properties has created an atmosphere and reputation around operating and former uranium mines that has led to very grave concerns amongst communities around the world. Thus the matter of remediation and future land use post-mining for these sites has become of great importance (Waggitt 2011a).

The introduction of Environmental impact Assessment processes (EIA) in the second half of the twentieth century required mine developers to show how they would manage environmental issues on new projects and mitigate adverse impacts during the operation. Initially there was only a vestigial requirement to show how the site would be remediated and managed into the future once mining had ceased. As time has gone on we have seen ever greater importance attached to this last part of the EIA. In part, this has come about as society has embraced the concepts of reduced impacts, sustainability and preservation of the natural environment. In some quarters this has been described as the balanced approach to mining and is often associated with the idea of a triple bottom line that is the outcome of a mining operation should achieve satisfactory outcomes in terms of economics, environmental performance and acceptance by the community (Waggitt 2011b). 
The achievement of the last two objectives will depend greatly on the final land use plan and the state of the site. Bare waste rock dumps, seeps of acid metalliferous drainage, polluted streams, remnant buildings, eroding landforms and weed infested grasslands are not likely to be acceptable to either regulators or local residents. Also the land should be capable of another use; it is important for future development that mining is not seen as a one-time land use which leaves the site fit for nothing afterwards. Above all the remediation plans must be effective, well implemented and demonstrably long lived. Community support for new developments will be based to some degree on the experiences people have had with previous developments.

Although we have many legacy sites around the world there are now several examples that miners and regulators can point to as examples of the modern balanced approach; these are sites where there is beneficial use. A number of these are uranium related sites which have attracted attention because of public perceptions on the risks and hazards of radioactivity. Much of what will be discussed here in the examples could be applied to any mine or at least considered for any mine site remediation program. Of course, there is no single universal solution and the planning for each project will require site-specific risk assessment and planning, taking into account local requirements of law as well as community wishes and practicality.

Uranium mining has been around a very long time, since the first recorded activities in the Ore Mountains of Saxony, but it is the mining since the advent of the 'Atomic Age' in the 1940s that is the subject of this review.

\section{Common concerns}

The most frequent concerns about mine closure expressed by communities seem to be the state of the site. Tailings dams, rock stockpiles, open pits, buildings, roads and so on that seem to be left behind with little or no thought for their future sue or management. What is important in planning mine closure is having a clear objective(s) for the end product, the closed out site and ongoing land use, and specific criteria by which to establish that the objective(s) has been achieved. Also it is important that this end product meets the requirements and expectations of all stakeholders, regulators, land owners and the community, to the extent practicable. All closure plans should aim to establish a site that is safe, stable, (physically and chemically) and non-polluting and that offers some ongoing, sustainable land use with a management requirement that is compatible with the foregoing items. Closure planning and setting of closure criteria have long been neglected and it is only relatively recently, perhaps the past 30 years or so, that the industry has begun to pay more attention to these matters. Often previous closure planning was only considered as closure commenced and this resulted in less than optimal outcomes.

Today the modern mining development will have an outline plan for closure as work commences. This will help avoid inefficient placement of wastes and residues during operations. However, while uranium mining has recently been near the forefront of such planning activities it was not always so. Unfortunately we have examples in many locations where uranium mining ended and sites were abandoned or remediation was undertaken in a perfunctory manner and without regard to any of the principles set out above. In some cases it has been necessary to return, sometimes more than once, to repeat or repair remediation; in some cases it has been necessary to undertake complete remediation from scratch of an abandoned site. With such operations costs are usually significantly higher than what would have been the cost to do the work in a structured manner as the operation closed down.

There are, however, examples of where the remediation and closure processes have been well organised and a successful post-mining land use established to achieve a sustainable and balanced outcome. In the following section a number of examples have been described.

\section{In situ leach uranium mine remediation}

The mining of uranium by in situ leach or in situ recovery (ISL-ISR) methods is now the preferred option for about $50 \%$ of current production. The process involves pumping out groundwater associated with suitable uranium rich deposits and extracting the dissolved uranium before returning the water below ground. This methodology allows the exploitation of deposits that may be quite deep and have low ore grades. The capital 
expenditure is relatively low and there is very little infrastructure at the surface. Certainly major excavations and waste rock stockpiles are not needed and process residues storage and disposal facilities are not required to be built.

The remediation of the ground surface at such sites is usually quite straightforward and in most cases there have been few problems in establishing a suitable vegetative cover. In some cases this has been a natural vegetation such as in the sites in South Australia. There the objective was to return the areas to a natural cover and this is being achieved successfully. The previous land uses of low density pastoral use or open bushland can be re-established.

In parts of the USA, such as Texas and Wyoming, a number of former ISL/ISR sites have been returned to a grass covered prairie like state and grazing livestock are now using the areas successfully. In some cases the cattle have even been able to graze during operations and so the transition at closure has been straightforward. The major concern is the condition of the groundwater from which the uranium was extracted. In all cases these waters were never likely to have been of great beneficial use due to the natural levels of radionuclides present. In modern ISL/ISR the addition of lixiviants to enhance uranium recovery has usually been controlled to minimise impacts and the flushing of several pore volumes through the borefields before closure has seen the water return to a condition no worse that the pre-mining state. In Kazakhstan it is estimated that natural attenuation will see waters return to a natural state within a maximum of 12 years with very little need for intervention by the operator (World Nuclear Association 2017).

\section{$4 \quad$ Conventional uranium mine remediation}

With many conventional uranium mines the greatest environmental hazards are rarely, if ever, radiation related, but more likely the sort of chemical and physical safety issues associated with any metalliferous mine. These include matters such as acid mine drainage, high levels of salts in seepage waters, physical stability of waste rock dumps and long-term security of tailings disposal sites. Regardless of the mine having been underground or open pit these issues have to be addressed when planning for a balanced outcome in terms of post-mining land use. Radiation hazards do however need to be assessed and managed additionally when planning closure of a uranium mine.

\subsection{Underground uranium mines}

The closure of underground mines, including uranium mines, may not often offer opportunities for further use as workings are often very deep and may suffer from water ingress. However, at Rosna in the Czech Republic it was announced in 2014 that the mining company was investigating options to turn part of the underground mine into a storage facility for natural gas and develop an underground research facility for the Radioactive Waste Repository Authority (World Nuclear News 2014). The Rosna mine closed in 2017 and the mine workings have been used as access to the proposed natural gas storage which will be located in the adjacent granite massif that was not mined for uranium. Work is suspended at the moment over financial issues. Another innovative use for a Czech uranium mine site has been the installation of photovoltaic cells on the embankment of the tailings dam at Dolni Rozinka. At this same site some small businesses have been allowed to lease buildings within the former processing complex where radioactive contamination is not an issue. The businesses have the advantage of well-established infrastructure and utilities as well as good access to road and rail links. This was observed during the site visit by participants at the 2013 meeting of the Uranium Mining and Remediation Exchange Group (UMREG) (Australasian Institute of Mining and Metallurgy 2014).

This use of former mine buildings associated with underground uranium facilities was also seen in France during the UMREG site visit in 2017 to the former mine site in Bellezane (operated by the then Areva company). Many examples are shown in the Ureka museum created by the operator at Bessines in France (www.ureka.fr/en/). There are similar examples in Germany of re-used facilities at former operational sites of the Wismut company, in particular the museum at Bad Schlema located in a former administration building. 
These mining companies in France and Germany had both underground and open pit operations and remediation of these has been a major activity since active uranium mining has been stopped in both countries for many years now.

\subsection{Open pit uranium mines and processing sites}

The most obvious remnants from open pit mining, apart from the voids themselves, are usually the associated waste rock stockpiles and often tailings disposal facilities in the form of dams or ponds. Sometimes the waste rock and/or tailings may have been used to backfill underground workings or mine voids, but such practices have come but recently to the industry in most cases, often as a result of later remediation programs. In particular the examples of Bellezane in France, many of the Uranium Mill Tailings Remedial Action (UMTRA) sites in USA and some works at Wismut sites as well as some work in Australia and Kyrgyzstan are examples of this. However, tailings relocation has not always led to a further land use, but may just be to provide better long-term containment for the material. A further option has been the use of the mine pit to dispose of tailings, as for example at Bellezane (France) and Nabarlek and Ranger (Australia). At Bellezane the disposal site has more recently been re-opened to accept the water treatment sludge and contaminated sediments from other Areva sites and local ponds elsewhere in the region.

In the case of the UMTRA tailings relocation sites in USA, the final containment cells are not released for a further purpose but retained under management by the Office of Legacy Management of the US Department of Energy, under the regulatory control of the Nuclear Regulatory Commission; in any event the nature of the final covers, which are usually a rip-rap, do not readily lend themselves to other uses, not least as vegetation is sometimes actively discouraged. Having said that there have been examples of plans to install photovoltaic (PV) installations on UMTRA tailings cells which passed an EIA but have yet to be implemented e.g. Durango (United States Department of Energy [US DoE] 2011).

Another good example of the use of an ex-uranium site for PV installations has been at Rifle in Colorado, USA. Here the riverside site of the former uranium mill was remediated and decontaminated. Subsequently the town council has built a waste water treatment plant and household waste recycling depot on the site. There are also two large PV arrays extending over 4.8 ha which provide about $60-70 \%$ of the daytime electrical power requirement to the plan (United States Environmental Protection Agency 2009). In France, at the former Lodéve mine and mill site, operated by Areva, the mill has been removed and the site cleared as well as the mining sites being remediated. The level area of the former mill has been serviced with utilities and roads and a small cardboard box manufacturer is now successfully established and in production at the site. Many of the waste rock piles have been reshaped and now have a combination of tree plantations and PV arrays established on them. Again the proximity of a community requires that the site is made safe, especially from drowning hazards. There is no public access to the site at present. Water treatment continues at the site, with onsite disposal of the residual sludge.

\subsubsection{Water filled voids}

In many cases the open void fills with water once mining ceases and this has often led to concerns about radiological and chemical safety. Whilst not all water filled voids from uranium mining have found acceptance two positive examples may be found in France at Puy de L'Age (Waggitt 2011c) and in Australia at Rum Jungle Creek South. At Puy de L'Age the mine site was landscaped and revegetated following cessation of mining whilst the water filled void was partially backfilled to create a shallow end about 2 metres deep. This shallow area was to create conditions suitable for fish species to live, such as black bass and trout. Once the pond has been suitably stocked the facility became a very popular fly fishing venue which functioned for many years as an active club and business. Today the facility is used only by staff of the former mining company Urano (formerly Areva) following some commercial arguments. However, the facility is safe and stable and longterm monitoring results have indicated the current situation is sustainable without further intervention. It is understood that routine monitoring by authorities has now ceased. 
At Rum Jungle Creek South (RJCS) (Northern Territory, Australia) the former mine pit filled with water and was abandoned. Later the local council was funded to undertake some landscaping works and the area was named Rum Jungle Recreation Lake. Unlike the well-known, and contaminated, Rum Jungle mine site located several $\mathrm{km}$ to the north the water quality at RJCS was found to be acceptable for recreational use and was used for both water sports training for kayaks and sailing dinghies as well as scuba diving training.

\subsubsection{Parklands, showgrounds, recreation and nature}

Remediated mine sites that are located close to populated areas may offer opportunities for various forms of urban renewal. Whilst the use of such sites for permanent occupation may not be encouraged they do allow open recreational space to be created in a variety of ways.

In Germany, between 1990 and 2011, the Wismut company undertook the remediation of the former Lichtenburg open pit on the Ronneburg mine site close to the centre of the town of Gera. Using the materials from the waste rock stockpiles in the vicinity the pit was backfilled with the most reactive materials being placed deep in the pit. Progressively the pit became a hill which was then shaped to become a landscape feature. The site was used as the venue for BUGA 2007, the federal German flower and horticulture show, even while some last works were continuing discretely in some more remote parts of the site. Within the site there are flower gardens, public open space, walking trails, an arboretum and a lookout from on the top of the hill with interpretive material. Wildlife has returned to some of the public open space areas and natural vegetation is establishing successfully. Some parts of the lower slopes have been used for large photovoltaic arrays and there is still a water treatment plant and residue disposal cell at the site. There have also been plans for other recreational facilities within the boundaries of the area. Other waste rock piles in the vicinity have been used for the backfilling or landscaped and revegetated. Overall the comprehensive remediation program at Ronneburg has to be considered a success (Paul \& Jahn 2015).

Elsewhere Wismut has been quite innovative with the creation of the golf course on the top of the former waste rock piles outside Schlema (www.golfpark-bad-schlema.de). This project has been well reported and provides another recreational facility in the town where remediation program has also included construction of a spa complex to replace the one torn down during the height of mining development (Wikipedia contributors 2019).

In the USA the former mill site in Grand Junction, Colorado, was rehabilitated as a part of the Department of Energy's UMTRA program (US DoE 2018). The cleared site has a prime riverside location not far from the centre of town and has been redeveloped with a number of features. Initially remediated to a flat grassy parkland with walking and cycling paths the area became popular as a recreation and picnic venue. Later developments on the site have included a native garden, a boutique brewery and restaurant and a sound stage with amphitheatre for musical and cultural performances. All these facilities are well patronised and some other small businesses have also now moved into the remaining parts of the area. Overall the zone is a good example of multiple land uses and all very sustainable.

In Gabon the former uranium mining area around Mounana has been remediated in a variety of ways. A former dam has been retained as a landscape feature and a café has been built on the shore and recreational boats may be rented to use on the lake. In other parts of the town, sites have been made safe and revegetated but the development of revegetation has not been uniform with some areas still not establishing well. Former mining company properties are still being used for housing in some cases.

At Nabarlek in Australia, the former mine and mill site was remediated in 1996 and revegetation was hoped to be well-established by now (Waggitt 2000). Whilst the site is stable and chemically and radiologically safe the vegetation cover is less than hoped for. Fires and cyclones have affected the site on several occasions; each time setting the growth back by a considerable amount. The site has yet to be signed off by the regulators and weed management continues at present in an effort to assist the natural plant species to take over the site. It is hoped that this site will be able to be accepted by the stakeholders before too many more years, at which point it will be considered for release by the regulators. 


\section{Conclusion}

Uranium mining, as for many other parts of the industry, has a history of remediation and subsequent land use that is far from perfect. However, many of the efforts have been successful. While we can look at sites like Rum Jungle and locations in Central Asia where remediation has either failed or been ignored there are other sites in Europe, Africa, America and Australia where remediation has been, or is being, successfully implemented with subsequent balanced land use as the end point. We have a long way to go in many cases, but the track record so far indicates we have the knowledge and technology and ability to be successful in establishing post-mining land uses that will meet regulatory requirements as well as the community's expectations. The funding of these programs can be problematic where they are legacy sites. Hopefully all current and more recent sites are suitably and securely bonded with $100 \%$ security deposits and with appropriate approved closure plans in place. Thus modern additions to the legacy mine inventory should no longer occur.

However, if the political will is there, we can only hope that progress will be made and continue to improve. If this can happen at uranium mine sites where there are extra and special community concerns,-and this paper shows that it can,-then there must be hope for the majority of uranium and all other mine sites to be eventually returned to some form of balanced and productive post-mining land use or, at the very least, be left in a state that is not a burden on succeeding generations.

\section{Acknowledgement}

I would like to take the opportunity to thank the many employers, colleagues and associates who, over the years, have facilitated my visiting the sites mentioned in this paper. It has been a privilege to work with you all.

\section{References}

Agricola, G 1556, De Re Metallica [Subject Metals], Dover Publications, Inc., New York.

Australasian Institute of Mining and Metallurgy 2014, AusIMM Bulletin, April 2014.

Paul, M \& Jahn, S 2015, 'The Ronneburg waste rock relocation project - Preliminary results of the performance monitoring period', Proceedings of WISSYM 2015, Wismut GmbH, Chemnitz, pp. 283-285.

United States Department of Energy 2011, Document LMS/DUD/SO6350DOE/EA-1770, Washington DC.

United States Department of Energy 2018, Grand Junction, Colorado, Disposal and Processing Sites, fact sheet, viewed 7 May 2019 https://www.Im.doe.gov/Grand_Junction_DP/Fact_Sheet_GJ.pdf

United States Environmental Protection Agency 2009, Success Stories - Siting Renewable Energy on Contaminated Land. New Rifle Uranium Mill Tailings Radiation Control Act (UMTRCA) Title 1 Site, Colorado.

Waggitt, PW 2000, 'Nabarlek uranium mine: From EIS to decommissioning', Proceedings of the International Symposium on the Process Metallurgy of Uranium, Canadian Institute of Mining, Metallurgy and Petroleum, Montreal.

Waggitt, P 2011a, 'Is there life after uranium mining? A global review', Proceedings of WISSYM 2011, Wismut GmbH, Chemnitz.

Waggitt, P 2011b, 'Modern uranium mining, the balanced approach', The AusIMM International Uranium Conference 2011 Abstracts, Australasian Institute of Mining and Metallurgy, Melbourne (CD).

Waggitt, P 2011c, 'Sustainability: the balanced approach to Modern Uranium Mining', in B Merkel \& M Schipek (eds), The New Uranium Boom. Challenge and Lessons Learned, Springer Heidelberg, Dordrecht.

Wikipedia contributors 2019, Bad Schlema, Wikipedia, The Free Encyclopedia, viewed 7 May 2019, https://en.wikipedia.org/wiki/Bad_Schlema

World Nuclear News 2014, 'Rožná uranium mine closing in 2017', World Nuclear News, viewed 7 May 2019, http://www.worldnuclear-news.org/ENF-Rozna-uranium-mine-closing-in-2017-1208201401.html

World Nuclear Association 2017, In Situ Leach Mining of Uranium, viewed 7 May 2019, http://www.world-nuclear.org/informationlibrary/nuclear-fuel-cycle/mining-of-uranium/in situ-leach-mining-of-uranium.aspx 